https://ejournal.iai-tribakti.ac.id/index.php/perbankan

\title{
Jual Beli Mata Uang Kuno Dalam Fikih Muamalah
}

\section{Buying and selling Ancient Currency in Muamalah Jurisprudence}

\author{
Kurnia Cahya Ayu Pratiwi ${ }^{1}$, Muh Nashirudin ${ }^{2}$ \\ ${ }^{1}$ Institut Agama Islam Negeri Surakarta, ${ }^{2}$ Institut Agama Islam Negeri Surakarta \\ ${ }^{1}$ kurnia.cap@gmail.com., ${ }^{2}$ muh.nashirudin@iain-surakarta.ac.id
}

\begin{abstract}
This article discusses a business that is currently being developed, namely the business of buying and selling ancient rupiah currency in the Triwindu market in Surakarta. In this transaction, the ancient rupiah currency was valued at a high price. Even so, many people are looking for these objects either from traders or collectors for non-business purposes without considering the muamalah aspect, namely in terms of the benefits that can be taken from the object. These objects are purchased to be used as wall hangings with the aim of following the trends or lifestyle of modern society. In this case, it is in accordance with Islamic law that buying and selling of similar goods must meet 2 requirements to avoid usury, namely: the same nominal and cash. This study uses field research methods by making the sources as the primary data source. The results of this study indicate that the practice of buying and selling ancient rupiah currency in terms of implementation is in accordance with Islamic law. This sale and purchase is declared legal and free from the element of usury, because the money which is used as the object of this sale and purchase is no longer a means of payment (antiques), so the exchange may be of a different nominal and not cash. In terms of its benefits, this sale and purchase is also legal if it is used for things that do not conflict with Islamic law.
\end{abstract}

Keywords: Jurisprudence Muamalah, Buying and Selling, Old Rupiah Money

\begin{abstract}
Abstrak
Artikel ini membahas bisnis yang saat ini sedang berkembang yaitu bisnis jual beli uang rupiah kuno di pasar Triwindu Surakarta. Dalam transaksi tersebut mata uang rupiah kuno dinilai dengan harga yang mahal. Meskipun demikian, banyak orang yang mencari benda tersebut baik dari kalangan para pedagang atau kolektor untuk keperluan non bisnis tanpa mempertimbangkan aspek muamalahnya,
\end{abstract}




\section{Kurnia Cahya, Nashirudin | Jual Beli Mata Kuang Kuno...}

yaitu dari segi kemanfaatan yang dapat diambil dari benda tersebut. Benda tersebut dibeli untuk dijadikan sebagai hiasan dinding dengan tujuan mengikuti tren atau gaya hidup masyarakat modern. Dalam permasalahan ini sesuai dengan hukum Islam bahwa jual beli barang sejenis harus memenuhi 2 syarat agar terhindar dari riba, yaitu: sama nominalnya dan tunai. Penelitian ini menggunakan metode penelitian lapangan (field research) dengan menjadikan narasumber sebagai sumber data primer. Hasil dari penelitian ini menunjukkan bahwa praktek jual beli mata uang rupiah kuno dari segi pelaksanaan sudah sesuai dengan hukum Islam. Jual beli ini dinyatakan sah dan terbebas dari unsur riba, karena uang yang dijadikan objek jual beli ini bukan lagi menjadi alat pembayaran (barang antik), sehingga dalam pertukarannya boleh dengan nominal yang berbeda dan tidak tunai. Ditinjau dari segi kemanfaatannya, jual beli ini juga dinyatakan sah apabila dipergunakan untuk hal-hal yang tidak bertentangan dengan syariat Islam.

Kata Kunci: Fikih Muamalah, Jual Beli, Uang Rupiah Kuno

\section{Pendahuluan}

Di era dewasa ini banyak sekali hal yang menarik perhatian tentang jual beli. Di mana jual beli tidak hanya bertujuan untuk memenuhi kebutuhan sehari-hari, namun berkembang menjadi sarana mencari keuntungan semata hingga kepada hal-hal yang bersifat memenuhi kepuasan. Oleh sebab itulah, bisnis mata uang kuno banyak diminati oleh kalangan masyarakat baik dari kalangan kolektor hingga pedagang biasa yang menginginkan keuntungan.

Bisnis ini boleh saja dilakukan, karena Islam tidak pernah membatasi manusia dalam melakukan jual beli. Menurut Imam Nawawi sebagaimana yang dikutip Dimyauddin Djuwaini mengatakan bahwa jual beli merupakan cara manusia berinteraksi satu dengan yang lain, bertukaran (harta dengan 
harta) dengan maksud untuk memilikinya. ${ }^{1}$ Yang dimaksud dengan harta dalam hal ini adalah semua yang dimiliki dan dapat dimanfaatkan. ${ }^{2}$

Berkaitan dengan jual beli tentunya tidak terlepas dari uang sebagai alat pembayaran. Namun sebelumnya akan digambarkan beberapa pengertian tentang uang. Para fuqaha mengemukakan bahwa, "Uang adalah apa yang digunakan manusia sebagai standar ukuran nilai harga dan media transaksi pertukaran". 3

Uang digunakan sebagai media transaksi pertukaran yang sah di seluruh dunia termasuk di Indonesia. Indonesia merupakan negara yang peredaran uangnya tidak pernah berhenti dan terus mengalami suatu perubahan. Adanya pergantian tipe uang lama dengan uang baru menjadi hal yang biasa dan membuat uang baru lebih disukai oleh masyarakat Indonesia. Namun terdapat pula uang-uang kuno yang sengaja disimpan sebagai koleksi karena keindahannya. Bahkan tidak sedikit pula yang sengaja mengoleksi karena peninggalan berharga dari nenek moyangnya.

Selain sebagai koleksi, beragam jenis uang kuno juga dijadikan sebagai sesuatu yang unik untuk diberikan kepada orang lain. Koleksi uang kuno koin atau kertas rupiah untuk pernikahan atau perkawinan pun sebagai salah satu contohnya. ${ }^{4}$ Uang-uang kuno tersebut tampak memukau dan berbeda ketika dijadikan sebagai mahar pernikahan dengan nominal yang unik tentunya.

Banyak masyarakat yang menyukai uang rupiah Indonesia dan menjadikannya sebagai koleksi ataupun mahar dalam suatu pernikahan

${ }^{1}$ Damyauddin Djuwaini, Pengantar Fiqh Muamalah, (Yogyakarta: Pustaka Pelajar, 2008), hlm. 69.

${ }^{2}$ Suhrawardi K. Lubis, Hukum Ekonomi Islam, (Jakarta: Sinar Grafika, 2004), hlm. 129.

${ }^{3}$ Ahmad Hasan, Mata Uang Islami: Telaah Komprehensif Sistem Keuangan Islami, terj. Saifurrahman Barito, Zulfikar Ali, (Jakarta: PT Raja Grafindo Persada, 2005), hlm. 910 .

${ }^{4}$ Puji Tri Astuti, Pembeli Uang Kuno, Wawancara Pribadi, 17 Februari 2017, jam $16.00-17.00$ WIB. 


\section{Kurnia Cahya, Nashirudin | Jual Beli Mata Kuang Kuno...}

dikarenakan keindahan yang dimiliki setiap uang-uang rupiah tersebut. Keindahan uang kuno rupiah tersebut sebenarnya merupakan gambaran dari sejarah uang rupiah itu sendiri sebagai mata uang resmi Indonesia. Sudah banyak pahlawan, daerah nusantara, hewan nusantara dan kebudayaan yang tergambar di mata uang rupiah. Banyak seri yang sudah dikeluarkan oleh pemerintah untuk mengganti, memperbaiki, dan menyempurnakan mata uang rupiah. Karena rupiah merupakan cerminan dari bangsa Indonesia.

Melihat fenomena di atas tentunya menjadi hal yang baru di bidang muamalah. Jual beli mata uang rupiah kuno merupakan bentuk perkembangan dari kemajuan kehidupan manusia, sehingga aturan hukumnya pun belum banyak dibahas dalam Al-Qur'an dan Hadis Nabi. Sedangkan praktek jual beli tersebut sudah banyak dilakukan di masyarakat.

Uang kuno yang dahulunya dianggap sebagai barang tidak berharga dan tidak memiliki manfaat, dewasa ini menjadi barang antik yang banyak diperjualbelikan di masyarakat, dan dapat menghasilkan keuntungan yang tidak sedikit jumlahnya. Fenomena ini tentunya banyak membuat orang tertarik untuk memiliki uang kuno sebagai koleksi tanpa mempertimbangakan manfaat yang dapat diambil dari uang tersebut. Barang antik yang hanya dijadikan sebagai hiasan dinding dengan tujuan mengikuti tren atau gaya hidup masyarakat modern. Sedangkan pengeluaran yang dibutuhkan untuk membeli uang-uang kuno terkesan mahal.

Dari uraian di atas selanjutnya akan dijelaskan tentang praktek jual beli mata uang rupiah kuno yang dilakukan oleh sebagian besar pedagang di pasar Triwindu Surakarta. Di pasar tersebut, masyarakat dapat menjual uang lama yang mereka miliki dan tentunya uang tersebut sudah tidak berlaku lagi di pasaran atau langka. Menariknya dalam transaksi tersebut mata uang rupiah kuno bisa dinilai dengan harga yang lebih mahal. Contohnya, uang koin 50 
rupiah berbahan nikel, bergambar burung cendrawasih dengan cetakan tahun 1971 tersebut dihargai sepuluh ribu rupiah. ${ }^{5}$

Melihat persoalan di atas, pertukaran mata uang rupiah (kuno) dengan mata uang rupiah sangatlah berbeda nominalnya. Sedangkan dalam Islam, persamaan jenis pertukaran dapat mengindikasikan riba jika nominalnya berbeda dan tidak tunai, dan hal ini menyebabkan tidak sahnya transaksi jual beli uang tersebut.

Penelitian ini memilih Pasar Triwindu dikarenakan pasar ini merupakan pasar yang khusus menyediakan barang-barang antik atau kuno yang berada di wilayah Surakarta. Dan menariknya lagi, sebagian pedagang di pasar ini masih menggunakan sistem barter dalam jual belinya.

\section{Metode}

Penelitian ini merupakan penelitian lapangan (field research) yaitu penelitian yang dilakukan di lapangan atau lokasi, di mana peristiwaperistiwa yang menjadi objek penelitian berlangsung, atau sumber-sumber primer dapat diketemukan. ${ }^{6}$ Objek dalam penelitian ini adalah praktek jual beli mata uang rupiah kuno di Pasar Triwindu Surakarta. Dalam melakukan penelitian ini, peneliti mengkaji praktek jual beli mata uang rupiah kuno dari aspek kemanfaatannya dan aspek riba. Teknik analisis data dalam penelitian ini ialah deskriptif kualitatif dengan menggunakan pola berpikir deduktif, yaitu membandingkan antara teori dengan kejadian kasuitis dari lapangan.

Data yang digunakan dalam penelitian ini adalah data primer, data sekunder dan data tersier. Data primer adalah data yang langsung berkaitan

\footnotetext{
5 Nanik, Penjual Uang Koin Kuno, Wawancara Pribadi, 14 Februari 2017, jam 10.00-11.00 WIB.

6 Taliziduhu Ndraha, Research: Teori, Metodologi, Administrasi, (Jakarta: PT Bina Aksara, 1985), hlm. 96.
} 


\section{Kurnia Cahya, Nashirudin | Jual Beli Mata Kuang Kuno...}

dengan objek penelitian. ${ }^{7}$ Data ini dapat diperoleh dari wawancara dengan informan dan observasi di Pasar Triwindu Surakarta. Sedangkan sumber data sekunder dalam penelitian ini meliputi data tertulis, berupa buku, majalah, arsip, dokumen pribadi dan dokumen resmi yang berkaitan dengan masalah teoritis dalam penelitian ini, khususnya mengenai permasalahan hukum jual beli dalam konteks fikih muamalah. ${ }^{8}$

\section{Jual Beli}

Kegiatan ekonomi Islam banyak sekali ragam dan jenisnya, salah satunya yang paling nyata dan dikenal orang dari zaman ke zaman adalah kegiatan jual beli, perdagangan, atau bisnis. ${ }^{9}$ Jual beli dikenal dan banyak dilakukan oleh masyarakat karena terdapat manfaat dan urgensi sosial, yang apabila dilarang akan menimbulkan berbagai kerugian. Berdasarkan hal ini, ulama fikih sepakat bahwa seluruh transaksi (jual beli) yang dilakukan manusia hukum asalnya adalah diperbolehkan, kecuali terdapat dalil yang melarangnya. ${ }^{10}$ Pernyataan ini diperkuat oleh pendapat Imam Syafi'i yang mengatakan bahwa, "Semua jenis jual beli hukumnya boleh kalau dilakukan oleh dua pihak yang masing-masing mempunyai kelayakan untuk melakukan transaksi, kecuali jual beli yang dilarang atau diharamkan dengan izin-Nya maka termasuk dalam kategori yang dilarang."11 Adapun selain itu maka jual beli boleh hukumnya selama berada pada bentuk yang ditetapkan oleh Allah SWT, seperti firmannya dalam surah An-Nisa' ayat 29. ${ }^{12}$

${ }^{7}$ Taliziduhu Ndraha, Research..., hlm. 60.

${ }^{8}$ Saifudin Azwar, Metode Penelitian, (Yogyakarta: Pustaka Pelajar, 1998), hlm. 91.

${ }^{9}$ Siti Nur Fatoni, Pengantar Ilmu Ekonomi: Dilengkapi Dasar-Dasar Ekonomi islam, (Bandung: Pustaka Setia, 2014), hlm. 187.

${ }^{10}$ Masjupri, Fiqh Muamalah 1, (Surakarta: FSEI Publishing, 2013), hlm. 7.

11 Wahbah Az-Zuhaili, Fiqh Islam Wa Adilatuhu, jilid 5, (Jakarta: Gema Insani, 2011), hlm. 25.

${ }^{12}$ Departeman Agama RI, Al-Qur'an dan Tafsirnya, jilid 2, (Jakarta: Lentera Abadi, 2010), hlm. 153. 
Surat An-Nisa' ayat 29 berisi larangan mengambil harta orang lain dengan jalan yang batil (tidak benar), kecuali dengan perniagaan yang berlaku atas dasar kerelaan bersama tanpa suatu paksaan. Karena jual beli yang dilakukan secara paksa tidak sah walaupun ada bayaran atau penggantinya. ${ }^{13}$ Dalam upaya mendapatkan kekayaan tidak boleh ada unsur zalim kepada orang lain, baik individu atau masyarakat. Tindakan memperoleh harta secara batil, misalnya mencuri, riba, berjudi, korupsi, menipu, berbuat curang, mengurangi timbangan, suap-menyuap, dan sebagainya.

Menurut Hendi Suhendi yang sebagaimana dikutip Siti Nur Fatoni mengatakan adanya kerelaan antar kedua belah pihak tidak dapat dilihat, karena kerelaan berhubungan dengan hati masing-masing pihak. ${ }^{14}$ Oleh karena itu, kerelaan dapat diketahui dengan melalui tanda-tanda lahirnya. Tanda yang menunjukkan kerelaan adalah ijab qabul.

Dalam transaksi jual beli tentunya terdapat rukun dan syarat yang harus dipenuhi. Menurut jumhur ulama sebagaimana yang dikutip Dr. Mardani, rukun jual beli ada tiga (3). ${ }^{15}$ Adapun rukun jual beli tersebut antara lain:

1. Pelaku transaksi, yang terdiri dari penjual dan pembeli;

2. Objek transaksi, yang terdiri dari harga dan barang.

3. Ijab qabul ${ }^{16}$

Agar jual beli dapat dilaksanakan secara sah dan memberi pengaruh yang tepat, harus direalisasikan beberapa syaratnya terlebih dahulu. Ada yang

${ }^{13}$ Departeman Agama RI, Al-Qur'an... hlm. 154.

${ }^{14}$ Siti Nur Fatoni, Pengantar Ilmu Ekonomi..., hlm. 190.

${ }^{15}$ Mardani, Fiqh Ekonomi Syariah: Fiqh Muamalah, (Jakarta: Kencana, 2012), hlm. 102.

${ }^{16}$ Menurut Hanafiyah, ijab adalah ucapan yang pertama-tama keluar dari kedua orang yang mengadakan perikatan (penjual), Misalnya, penjual berkata, "Aku jual kepadamu". Sedangkan qabul adalah ucapan seorang pembeli saat menerima barang tersebut. Misalnya, pembeli berkata "Aku telah membeli ini dari kamu seharga 1.000 (seribu) rupiah". Lihat Siah Khosyi'ah, Fiqh Muamalah Perbandingan, (Bandung: Pustaka Setia, 2014), hlm. 85. 


\section{Kurnia Cahya, Nashirudin | Jual Beli Mata Kuang Kuno...}

berkaitan dengan pelaku jual beli dan ada kaitannya dengan objek yang diperjualbelikan.

Pertama, yang berkaitan dengan pihak-pihak pelaku jual beli, harus memiliki kompetensi dalam melakukan aktivitas itu, yakni dengan kondisi yang sudah baligh serta berkemampuan memilih. ${ }^{17}$ Selain itu pelaku jual beli juga harus memenuhi syarat seperti berakal (tidak gila), kehendak sendiri, dan tidak mubadzir (pemboros). ${ }^{18}$

Kedua, yang berkaitan dengan objek jual beli, yakni bendanya harus suci, ada manfaatnya (bernilai), telah ada pada waktu jual beli dilakukan, dapat ditentukan, diketahui secara jelas oleh kedua belah pihak, dan dapat diserahkan pada waktu jual beli dilakukan. ${ }^{19}$ Berkaitan dengan harga harus disepakati secara jelas dan dapat diserahkan secara langsung ataupun sesuai kesepakatan.

Kemanfaat suatu objek jual beli menjadi syarat yang mutlak dalam suatu transaksi. Hal ini dapat terlihat jelas dari kaidah fikih yang berhubungan dengan jual beli sebagaimana yang dikemukakan oleh Enang Hidayat, bahwa "Hukum asal setiap sesuatu yang sah dimanfaatkannya, maka sah pula diperjualbelikannya kecuali adanya dalil yang mengharamkannya."20 Kaidah ini menjelaskan tentang objek yang bisa diperjualbelikan dan dimanfaatkannya. Adapun syarat-syarat barang yang dapat diperjualbelikan dan dimanfaatkan antara lain sebagai berikut:

1. Syarat pertama, benda yang diperjualbelikan itu ada manfaatnya. Dengan demikian benda yang tidak ada manfaatnya sama sekali tidak bisa

17 Abdullah Al-Mushlih dan Shalah Ash-Shawi, Fikih Ekonomi Keuangan Islam, (Jakarta: Darul Haq, 2004), hlm. 92.

18 Masjupri, Fiqh Muamalah..., hlm. 107.

19 Ahmad Azhar Basyir, Asas-Asas Hukum Muamalat (Hukum Perdata Islam), (Yogyakarta: UII Press, 2000), hlm. 78.

20 Enang Hidayat, Fiqih Jual Beli, (Bandung: PT Remaja Rosdakarya, 2015), hlm. 61. 
dijadikan objek jual beli, karena hukumnya tidak sah. Selain itu termasuk menginfakkan harta yang tidak ada manfaatnya termasuk ria-ria atau mubazir, seperti serangga yang tidak bisa diperjualbelikan karena tidak ada manfaatnya.

2. Syarat kedua, manfaat benda tersebut diperbolehkan oleh syara'.

Barang yang tidak ada manfaatnya sama sekali, hukumnya tidak diharamkan juga tidak diperbolehkan. ${ }^{21}$ Misalnya serangga, dan yang semisalnya. Dalam hal ini para ulama sepakat hukumnya tidak boleh memanfaatkan dan memperjualbelikannya. Karena hal tersebut termasuk menyianyiakan harta yang hukumnya diharamkan. Namun pada perkembangannya, serangga menjadi barang yang bermanfaat karena digunakan untuk memberi pakan binatang peliharaan seperti burung. Dan hal ini menjadikan serangga banyak diperjualbelikan di masyarakat modern.

\section{Harta (Amwal)}

Pada prinsipnya, jual beli mata uang rupiah kuno tidak berbeda dengan jual beli pada umumnya. Mata uang rupiah kuno merupakan benda yang dipandang sebagai harta $(m a>l)$, yaitu meliputi benda berwujud yang berharga dan bernilai terutama bagi Numismatik. ${ }^{22}$

Menurut Kompilasi Hukum Ekonomi Syariah Pasal 1 ayat (9), amwa>l (harta) adalah benda yang dapat dimiliki, dikuasai, diusahakan, dan dialihkan, baik benda berwujud maupun tidak berwujud, baik benda terdaftar maupun yang tidak terdaftar, baik benda yang bergerak maupun yang tidak

\footnotetext{
${ }^{21}$ Hidayat, Fiqih Jual Beli.. hlm. 63.

${ }^{22}$ Suhrawardi K. Lubis, Hukum Ekonomi Islam..., hlm. 129.
} 


\section{Kurnia Cahya, Nashirudin | Jual Beli Mata Kuang Kuno...}

bergerak dan hak yang mempunyai nilai ekonomis. ${ }^{23}$ Ulama membagi harta dilihat dari berbagai segi, antara lain $^{24}$ :

1. Dilihat dari aspek kebolehan memanfaatkannya oleh syara', harta dibagi kepada mal mutaqawwim dan ghairu mutaqawwim.

2. Dilihat dari segi dapat atau tidaknya dipindahkan, harta dibagi kepada iqar dan manqul.

3. Dilihat dari segi ada atau tidak adanya harta sejenis di pasaran, harta dibagi kepada harta mitsli dan qimi.

Berkaitan dengan jual beli mata uang rupiah kuno di atas, maka uang kuno tersebut termasuk harta $q i m i^{25}$. Termasuk jenis harta ini dikarenakan mata uang rupiah kuno termasuk harta (benda) yang susah didapatkan di pasaran (terjadi kelangkaan), jika pun terjadi persamaan, maka itu hanya terbatas pada ukurannya, karena setiap mata uang memiliki nomor seri yang berbeda-beda tiap lembarannya.

\section{Riba}

Riba adalah penambahan jumlah hutang dalam waktu yang ditentukan karena masa pinjaman dipanjangkan waktunya, atau orang yang meminjam tidak mampu membayar pada waktu yang telah ditentukan. ${ }^{26}$

Dalam jual beli mata uang rupiah kuno terdapat persamaan jenis pertukaran, yaitu antara mata uang dengan mata uang. Maka hal ini dapat

\footnotetext{
${ }^{23}$ Pasal 1 Kompilasi Hukum Ekonomi Syariah. Lihat Pusat Pengkajian Hukum Islam dan Masyarakat Madani (PPHIMM), Kompilasi Hukum Ekonomi Syariah, (Jakarta: Kencana, 2009), hlm. 3.

${ }^{24}$ Ghufron A. Mas'adi, Fiqh Muamalah Kontekstual, (Jakarta: PT RajaGrafindo Persada, 2002), hlm. 20.

${ }^{25}$ Harta qimi adalah harta yang tidak terdapat padanannya di pasaran, atau terdapat padanannya, akan tetapi nilai tiap satuannya berbeda, seperti hewan, rumah, berbagai jenis karpet, intan dan mutiara. Lihat Dimyauddin Djuwaini ${ }_{s}$ Pengantar Fiqh ..., hlm. 30. hlm. 127.

${ }^{26}$ Mustaq Ahmad, Etika Bisnis dalam Islam, (Jakarta: Pustaka Al-Kautsar, 2001),
} 
mengindikasikan adanya riba jika tidak memenuhi 2 (dua) syarat sebagai berikut $^{27}$ :

1. Ukuran keduanya harus sama, berat (jika satuan barang berdasarkan timbangan) atau volume (jika satuan barangnya berupa liter).

2. Serah terima kedua barang harus tunai di majelis akad, tidak boleh 10 gram emas Singapura diterima sekarang dan 10 gram emas Jakarta diserahkan dilain hari.

Apabila kedua syarat tersebut tidak dipenuhi, maka para ulama sepakat bahwa transaksi yang dilakukan itu dinyatakan tidak sah. ${ }^{28}$ Hal ini sesuai dengan hadis Nabi SAW yang diriwayatkan dari Ubadah bin Shamit r.a :

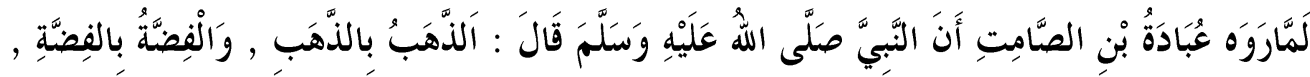

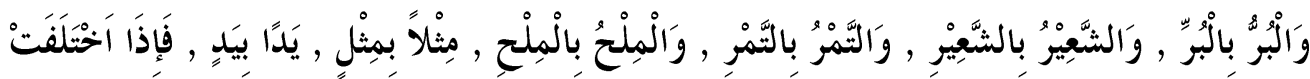

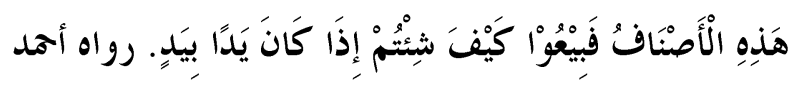

Artinya: Ubadah bin Ash-Shamit r.a. meriwayatkan bahwa Rasulullah SAW bersabda: (pertukaran) antara emas dengan emas, perak dengan perak, gandum dengan gandum, sya'ir dengan sya'ir, kurma dengan kurma, garam dengan garam itu harus sama dan dibayar kontan. Jika berbeda (penukaran) barang di atas, maka juallah barang tersebut sekehendak kamu sekalian dengan syarat dibayar kontan. ${ }^{29}$

Jika ditelaah, hadis tersebut menjelaskan tentang 2 kelompok barangbarang ribawi (amwal ribawiyat), kelompok pertama adalah mata uang atau uang, dan kelompok kedua adalah makanan.

${ }^{27}$ Erwandi Tarmizi, Harta Haram Muamalat Kontemporer, (Bogor: PT Berkat Mulia Insani, 2017), hlm. 531.

${ }^{28}$ Ibid., hlm. 531.

29 Adiwarman A. Karim dan Oni Sahoni, Riba, Gharar dan Kaidah-Kaidah Ekonomi Syariah: Analisis Fikih Ekonomi, (Jakarta: Rajawali Pers, 2015), hlm. 29. 


\section{Kurnia Cahya, Nashirudin | Jual Beli Mata Kuang Kuno...}

Menurut Dr. Erwandi Tarmizi, riba $b a^{\prime} i$ yaitu riba yang objeknya adalah akad jual beli terbagi menjadi 2 (dua), yaitu ${ }^{30}$ :

1. Riba fadhl yaitu menukar satu dari 6 jenis harta riba (emas, perak, kurma, gandum, (sya'ir) gandum jenis murah dan garam) dengan yang sejenis dan ukuran berbeda.

2. Riba nasi'ah yaitu menukar salah satu harta riba dengan harta riba lainnya yang sejenis atau berlainan jenis akan tetapi 'illatnya sama (yaitu: emas dan perak illatnya alat tukar. Kurma, gandum, sya'ir, dan garam 'illatnya makanan pokok dan tahan lama) dengan cara tidak tunai.

\section{Praktek Jual Beli Mata Uang Rupiah Kuno Ditinjau Dari Segi Rukun Dan Syarat}

Jual beli adalah tukar menukar harta dengan harta secara suka sama suka (kerelaan). ${ }^{31}$ Kalimat tersebut mengandung maksud bahwa kegiatan mengalihkan hak dan pemilikan itu berlangsung secara timbal balik atas dasar kehendak dan keinginan bersama (kerelaan).

Kerelaan kedua belah pihak menjadi prinsip jual beli yang harus terpenuhi. Karena jual beli yang dilakukan secara terpaksa hukumnya tidak sah walaupun ada bayaran atau penggantinya. ${ }^{32}$ Pada dasarnya kerelaan kedua belah pihak tidak dapat dilihat, karena kerelaan berhubungan dengan hati masing-masing pihak. Oleh sebab itu, kerelaan dapat diketahui dengan tanda-tanda lahirnya berupa ijab qabul. ${ }^{33}$

Dalam transaksi jual beli tentunya terdapat rukun dan syarat yang harus dipenuhi, salah satunya objek jual beli. Pada prinsipnya barang yang menjadi objek jual beli memiliki persyaratan yang harus dipenuhi, antara lain: suci,

${ }^{30}$ Erwandi Tarmizi, Harta Haram ..., hlm. 530.

31 Amir Syarifuddin, Garis-Garis Besar Fiqh, (Jakarta: Kencana, 2012), hlm. 193.

32 Departemen Agama RI, Al-Qur'an danTafsirnya, jilid 2..., hlm. 154.

33 Siti Nur Fatoni, Pengantar Ilmu Ekonomi..., hlm. 190. 
memiliki manfaat, telah ada pada waktu jual beli dilakukan, dapat ditentukan, diketahui secara jelas oleh kedua belah pihak, dan dapat diserahkan pada waktu jual beli dilakukan. ${ }^{34}$ Apabila salah satu syarat dalam objek jual beli ini tidak terpenuhi, maka menurut ulama Hanafiyah akadnya menjadi menjadi batil. ${ }^{35}$

Adapun perbanndingan rukun jual beli antara ketentuan hukum Islam dengan praktek yang ada di lapangan, maka akan disajikan tabel perbandingannya.

\section{Tabel 1}

Perbandingan Ketentuan Hukum Islam dengan Praktek Jual Beli Mata Uang Rupiah Kuno

\begin{tabular}{|c|c|c|c|}
\hline No & Hal & $\begin{array}{c}\text { Ketentuan Jual Beli } \\
\text { Dalam Islam }\end{array}$ & $\begin{array}{c}\text { Praktek Jual Beli Mata } \\
\text { Uang Rupiah Kuno }\end{array}$ \\
\hline & 'Áqidain & $\begin{array}{l}\text { Ada dua pihak yang } \\
\text { melakukan transaksi } \\
\text { jual beli. }\end{array}$ & $\begin{array}{l}\text { ada dua pihak yang } \\
\text { melakukan transaksi jual } \\
\text { beli, yaitu penjual dan } \\
\text { pembeli mata uang rupiah } \\
\text { kuno. }\end{array}$ \\
\hline 2. & Ma'qûd 'Alaih & $\begin{array}{l}\text { a. Ada barang yang } \\
\text { dijadikan objek } \\
\text { jual beli }\end{array}$ & $\begin{array}{l}\text { - Ada mata uang rupiah } \\
\text { kuno yang dijadikan objek } \\
\text { jual beli, } \\
\text { - Nilai nominal mata uang } \\
\text { rupiah kuno, gambar pada } \\
\text { uang kuno (kertas) yang }\end{array}$ \\
\hline
\end{tabular}

34 Ahmad Azhar Basyir, Asas-Asas Hukum Muamalat ..., hlm. 78.

35 Enang Hidayat, Fiqh Jual Beli..., hlm. 50. 
Kurnia Cahya, Nashirudin | Jual Beli Mata Kuang Kuno...

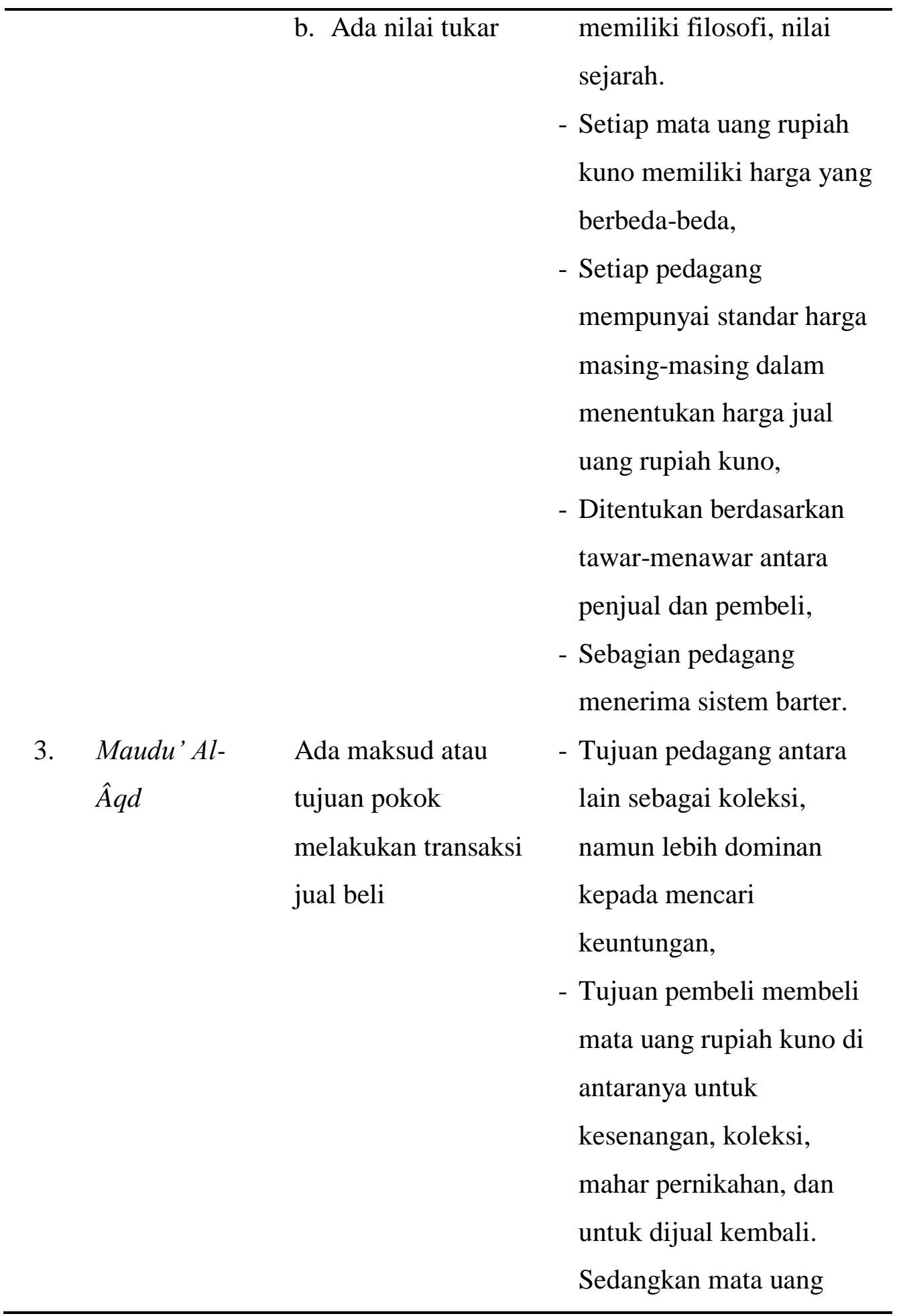




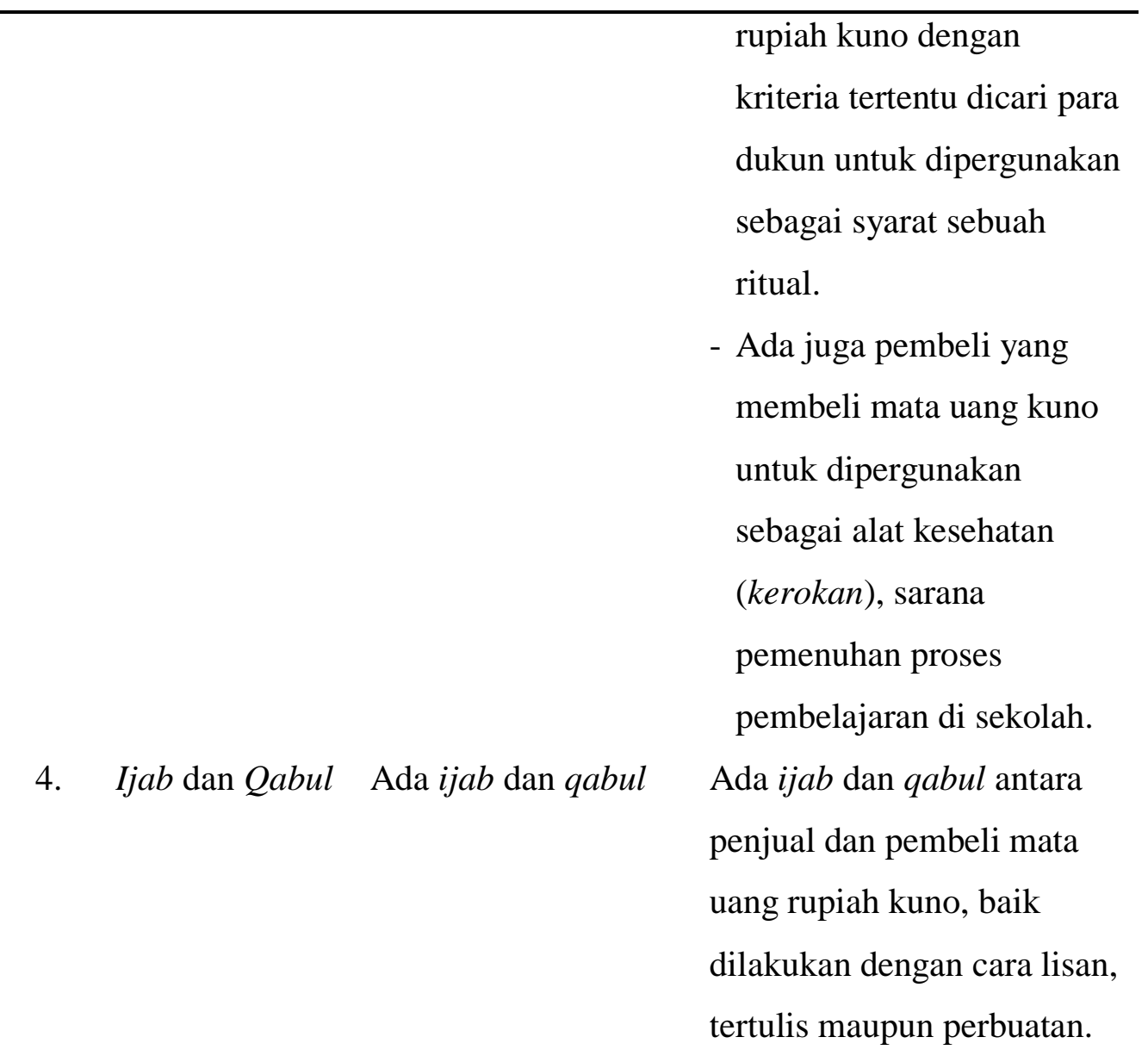

Sumber:

Hasil Wawancara Pedagang Mata Uang Rupiah Kuno di Pasar Triwindu Surakarta

Untuk menganalisis praktek jual beli mata uang rupiah kuno di pasar Triwindu Surakarta, maka secara sistematis akan diuraikan dalam sub-sub bagian sebagai berikut:

1. Mengenai âqidain atau orang yang melakukan transaksi jual beli

Para pihak yang terlibat dalam transaksi jual beli mata uang rupiah kuno di pasar Triwindu Surakarta terdiri dari dua pihak, yaitu pihak pertama sebagai penjual mata uang rupiah kuno dan pihak kedua sebagai pembeli mata uang rupiah kuno. 


\section{Kurnia Cahya, Nashirudin | Jual Beli Mata Kuang Kuno...}

Para imam mazhab sepakat bahwa jual beli itu dianggap sah jika dilakukan oleh orang yang sudah balig, berakal, kemauan sendiri, dan berhak membelanjakan hartanya. ${ }^{36}$ Namun para imam mazhab berbeda pendapat mengenai jual beli yang dilakukan oleh anak kecil. Menurut pendapat Maliki dan Syafi'i adalah tidak sah. Sedangkan menurut Hanafi dan Hambali adalah sah jika ia telah mumayyiz (dapat membedakan yang baik dan yang buruk). Hanafi dan Hambali menganggap sah jual beli yang dilakukan anak kecil tersebut namun dengan syarat mendapat izin terlebih dahulu dari walinya.

Rasya Daniar Faiz merupakan salah satu pembeli mata uang kuno di pasar Triwindu Surakarta yang masih berusia 11 tahun. Dalam Islam anak laki-laki yang berusia dibawah 15 tahun dan belum mimpi basah dianggap belum balig sehingga menurut Maliki dan Syafi'i hukumnya tidak sah. Namun menurut Hanafi dan Hambali sah dengan syarat mendapat izin dari walinya, dalam hal ini orang tua. Ketika rasya membeli uang kuno di pasar Triwindu, ia didampingi oleh ayahnya, ${ }^{37}$ sehingga transaksi tersebut dapat dinyatakan sah jika melihat pendapat Hanafi dan Hambali karena mendapat izin orang tuanya.

Kedua belah pihak yang terlibat dalam transaksi jual beli mata uang rupiah kuno di pasar Triwindu pada umumnya sudah memenuhi syarat untuk melakukan transaksi jual beli. Keduanya adalah orang yang sudah balig, berakal dan mampu untuk berbuat hukum. Pada saat melakukan transaksi tidak dalam keadaan kehilangan akal dan dilakukan atas dasar saling rela (suka sama suka).

\footnotetext{
${ }^{36}$ Muhammad bin 'Abdurrahman Ad-Dimasyqi, Fiqih Empat Mazhab, terj Abdullah Zaki Alkaf, (Bandung: Hasyimi, 2014), hlm. 204.

${ }^{37}$ Rasya Daniar Faiz, Pembeli Uang Kuno, Wawancara Pribadi, 22 Mei 2017, jam $18.30-19.00 \mathrm{WIB}$
} 


\section{Mengenai ma'qûd 'alaih}

Yang menjadi objek dalam transaksi jual beli pada penelitian ini adalah mata uang rupiah kuno. Untuk melihat keabsahannya jual beli mata uang kuno, barang ini harus memenuhi syarat objek jual beli di antaranya suci, bermanfaat, diketahui secara jelas oleh kedua belah pihak, telah ada pada waktu jual beli dilakukan, dapat ditentukan, dan dapat diserahkan pada waktu jual beli dilakukan.

Mata uang rupiah kuno merupakan barang yang suci dan dapat disucikan. Jika dilihat dari kejelasan barangnya, dapat terlihat dari cara pedagang berjualan, karena mata uang kuno yang diperjualbelikan tertata rapi di depan toko sehingga pembeli dapat mengetahui spesifikasi mata uang kuno yang ingin dibelinya, terutama kondisinya. ${ }^{38}$ Jika pembeli membeli secara online atau pesanan pun kejelasannya tidak perlu diragukan, karena penjual secara detail memberikan spesifikasi mata uang kuno yang diinginkan oleh pembeli disertai dengan foto mata uang kuno tersebut. ${ }^{39}$

Dengan demikian dapat diketahui juga bahwa uang kuno yang diperjualbelikan itu telah ada dan dapat diserahkan pada waktu transaksi tersebut dilakukan kecuali pada pesanan. Uang rupiah kuno yang dipesan sudah ada tetapi penyerahannya sesuai dengan kesepakatan kedua belah pihak.

Untuk melihat kemanfaatan mata uang kuno dapat diukur dengan menggunakan kriteria agama. Dimana pemanfaatan barang jangan sampai

${ }^{38}$ Observasi Teknik Berjualan Penjual Mata Uang Rupiah Kuno di Pasar Triwindu Surakarta, 17 Mei 2017.

${ }^{39}$ Derino Ady Saputro, Pedagang Uang Kuno, Wawancara Pribadi, 16 Mei 2017, jam 13.00 - 14.00 WIB. Yoyo, Pedagang Uang Kuno, Wawancara Pribadi, 17 Mei 2017, jam 14.00 - 15.00 WIB. Sri Bagong, Pedagang Uang Kuno, Wawancara Pribadi, 25 Mei 2017, jam 10.00 - 10.20 WIB. Maya Putri Indriyani, Pedagang Uang Kuno, Wawancara Pribadi, 25 Mei 2017, jam 11.00 - 11.20 WIB. 


\section{Kurnia Cahya, Nashirudin | Jual Beli Mata Kuang Kuno...}

bertentangan dengan agama, peraturan perundang-undangan, kesusilaan, maupun ketertiban umum yang ada di dalam kehidupan bermasyarakat.

Dalam Islam, segala jenis barang boleh untuk diperjualbelikan. Namun barang yang menjadi objek jual beli haruslah barang yang dinilai sebagai harta $(a l-m a>l)$. Sesuatu yang bukan harta tidak pantas dijadikan harta dan dimiliki. Begitu juga harta yang tidak mempunyai nilai menurut syara' tidak halal diperjualbelikan kecuali harta tersebut dapat dimanfaatkan pada jalan yang diperbolehkan oleh syara', baik dengan cara dimakan, diminum, ditunggangi, dan lain sebagainya.

Dari pemaparan di atas dapat diketahui begitu pentingnya nilai kemanfaat suatu barang untuk menilai keabsahan suatu jual beli. Selain itu memperjualbelikan barang yang bermanfaat merupakan salah satu cara manusia menjaga hartanya dari perbuatan mubazir (boros). Berikut kaidah fikih jual beli yang berkaitan dengan kemanfaatan barang:

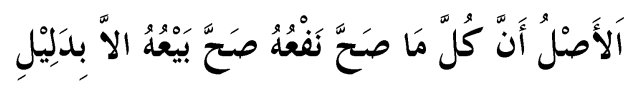

Artinya: Hukum asal setiap sesuatu yang sah dimanfaatkannya, maka sah pula diperjualbelikannya, kecuali adanya dalil yang mengharamkannya. ${ }^{40}$

Mata uang kuno yang diperjualbelikan di pasar Triwindu Surakarta pada umumnya dipergunakan untuk kesenangan, hobi, koleksi, dan mahar pernikahan. Ada juga yang membeli untuk sarana pemenuhan proses pembelajaran di sekolah, dan alat kesehatan (kerokan) seperti uang benggol. ${ }^{41}$ Ada juga mata uang rupiah kuno dengan kriteria tertentu yang di

\footnotetext{
${ }^{40}$ Enang Hidayat, Fiqh Jual Beli..., hlm. 61.

${ }^{41}$ Yoyo, Pedagang Uang Kuno, Wawancara Pribadi, 17 Mei 2017, jam 14.00 - 15.00
} WIB. Sri Bagong, Pedagang Uang Kuno, Wawancara Pribadi, 25 Mei 2017, jam 10.00 10.20 WIB. 
cari para dukun untuk dipergunakan sebagai syarat sebuah ritual, uang ini biasanya disebut dengan uang $u k a-u k a .^{42}$

Uang kuno yang diperjualbelikan dengan tujuan untuk kesenangan, hobi, koleksi dan mahar pernikahan hukumnya sah karena tidak bertentangan dengan agama, peraturan perundang-undangan, kesusilaan, maupun ketertiban umum yang ada di dalam kehidupan bermasyarakat. Selain itu mata uang rupiah kuno merupakan benda yang tidak diharamkan dalam Islam untuk diperjualbelikan. Hal ini diperkuat dengan pendapat Komisi Fatwa dan Riset Ilmiah KSA bahwa: "Selama benda itu tidak tercampur dengan benda yang haram maka boleh untuk diperjualbelikan". ${ }^{43}$ Jika mengandung kombinasi yang haram, maka haram diperjualbelikan.

Sedangkan jual beli mata uang rupiah kuno yang dilakukan dengan tujuan untuk syarat sebuah ritual hukumnya tidak sah karena jual beli seperti ini melanggar ketentuan agama. Menurut Syekh Abdurrahman As-Sa'di, jual beli yang dilakukan dengan tujuan untuk membantu kemaksiatan atau melakukan perbuatan haram, maka jual beli seperti itu tidak diperbolehkan dan tidak sah. ${ }^{44}$

3. Mengenai maudu' al-âqd atau tujuan pokok mengadakan akad

Pada dasarnya jual beli mata uang rupiah kuno mengandung tujuan yang baik atau maslahah. Karena pemindahan kepemilikan dari penjual kepada pembeli dengan imbalan. Bagi penjual mata uang rupiah kuno, jual beli barang ini menjadi ladang penghasilan yang menjanjikan untuk

${ }^{42}$ Derino Ady Saputro, Pedagang Uang Kuno, Wawancara Pribadi, 16 Mei 2017, jam 13.00 - 14.00 WIB. Adi, Pedagang Uang Kuno, Wawancara Pribadi, 17 Mei 2017, jam 13.00 - 14.00 WIB.

${ }^{43}$ Majalah Mawaddah, Edisi 11, Tahun Ke-1, Jumadil Ula - Jumadil Tsaniyah 1429 H (Juni 2008). Lihat Redaksi Konsultasi, “Bolehkah Jual Beli Benda-Benda Antik?" dikutip dari http://konsultasisyariah.com diakses 6 Mei 2017.

44 Abdurrahman as-Sa'di, dkk, Fiqih Jual-Beli: Panduan Praktis Bisnis Syariah, terj Abdullah. (Jakarta: Senayan Publishing, 2008), hlm. 144. 


\section{Kurnia Cahya, Nashirudin | Jual Beli Mata Kuang Kuno...}

memenuhi kebutuhan sehari-harinya karena pedagang yang berjualan di pasar Triwindu Surakarta menjadikan barang antik menjadi sumber pokok mata pencahariannya.

Sedangkan bagi pembeli, dengan adanya transaksi jual beli ini, mereka dapat memperoleh mata uang rupiah kuno yang diinginkannya baik digunakan sebagai hobi, koleksi, mahar pernikahan, alat kesehatan maupun sarana proses pembelajaran.

4. Mengenai ijab dan qabul

Ijab dan qabul dalam praktek jual beli mata uang rupiah kuno di pasar Triwindu Surakarta dilakukan secara lisan, dimana penjual mengucapkan kalimat ijab dan pembeli mengucapkan kalimat qabul sebagaimana yang tergambarkan pada BAB III. Sedangkan pada jual beli online dan/atau pesanan, ijab dan qabul dilakukan secara tertulis dan/atau perbuatan setelah adanya proses tanya jawab atau konfirmasi mengenai mata uang rupiah kuno yang ingin dibeli. Dengan demikian ijab dan qabul yang dipraktekan antara penjual dan pembeli di pasar Triwindu Surakarta sudah benar menurut kebiasaan masyarakat ('urf), baik dilakukan dengan cara lisan, tulisan dan perbuatan.

\section{Riba pada jual beli mata uang rupiah kuno}

Tukar menukar 6 komoditi riba (emas, perak, gamdum, sya 'ir, kurma dan garam) dengan jenis yang sama harus dilakukan secara tunai dengan nominal yang sama. Ketentuan ini berdasarkan sabda Nabi SAW yang berbunyi: 


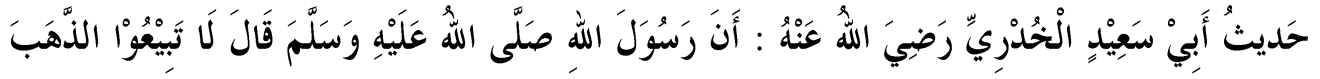

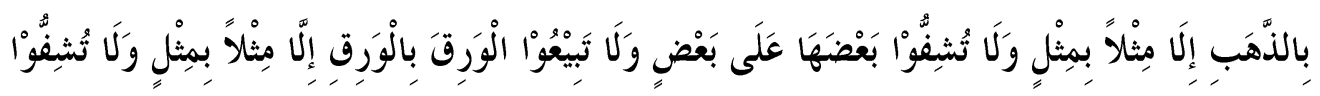

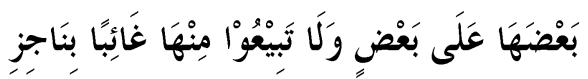

Artinya: Diriwayatkan dari Abi Sa'id Al-Khudri radhiyallahu 'anhu, dia telah berkata: Sesungguhnya Rasulallah shallallahu 'alaihi wa sallam telah bersabda: "Janganlah kamu menjual emas dengan emas (mata uang) kecuali sama jumlahnya serta janganlah melebihkan sebagiannya. Kemudian janganlah kamu menjual perak dengan perak kecuali sama jumlahnya serta janganlah melebihkan sebagiannya dan janganlah menjualnya dengan cara sebagian secara tunai dan sebagian lagi ditangguhkan". ${ }^{45}$ (Muttafaq ‘Alaih)

Jika ditelaah dari hadis di atas menjelaskan tentang 2 kelompok barang-barang ribawi. Kelompok pertama adalah mata uang atau uang dan kelompok kedua adalah makanan. ${ }^{46}$ Namun pada penelitian ini akan lebih berfokus kepada pembahasan mata uang yang diqiyaskan dengan emas dan perak.

Dalam menentukan illat emas dan perak, para ulama memiliki perbedaan pendapat. Menurut Erwandi Tarmizi, perbedaan pendapat ini dibagi menjadi 3, di antaranya: ${ }^{47}$

1. Pendapat pertama mengatakan bahwa illat riba untuk emas dan perak adalah satuan berat dan sejenis. Pendapat ini dikemukakan oleh mazhab Hanafi dan Hanbali.

45 Ahmad Mudjab Mahalli dan Ahmad Rodli Hasbullah, Hadis-Hadis Muttafaq 'Alaih: Bagian Munakahat dan Mu'amalat, (Jakarta: kencana, 2004), hlm. 114.

46 Adiwarman A. Karim dan Oni Sahoni, Riba, Gharar ..., hlm. 29.

${ }^{47}$ Erwandi Tarmizi, Harta Haram Muamalat ..., hlm. 535. 


\section{Kurnia Cahya, Nashirudin | Jual Beli Mata Kuang Kuno...}

Pada waktu itu, emas dan perak merupakan komoditi yang satuannya adalah ditimbang, maka timbangan dapat dijadikan illat riba untuk komoditi ini.

Pendapat ini memiliki konsekuensi bahwa uang kartal ${ }^{48}$ dewasa ini tidak dapat dianalogikan dengan emas dan perak karena uang kartal dihitung berdasarkan nominal yang tertera pada lembarannya dan tidak dihitung dengan berdasarkan timbangan.

2. Pendapat kedua mengatakan bahwa illat riba emas dan perak adalah ghulabat tsamaniyah (dominasi sebagai alat tukar). Pendapat ini dikemukakan oleh mazhab Syafi'i dan Maliki.

3. Pendapat ketiga menyatakan bahwa illat riba emas dan perak muthlaq tsamaniyah (mutlak sebagai alat tukar) atau qiyamul asy yaa' (pegukur nilai harga). Pendapat ini didukung oleh As-Syirazi (ulama mazhab Syafi'i) dan sebagian ulama mazhab Maliki.

Maksud dari illat ini bahwa emas dan perak dikategorikan sebagai komoditi riba dikarenakan emas dan perak sebagai alat pembayaran dan sebagai nilai harga barang dan jasa di waktu itu, maka jika dikemudian hari disepakati alat pembayaran dari material yang lain selain emas dan perak hukumnya sama dengan emas dan perak. Dan pendapat inilah yang dinilai mendekati kebenaran, karena illat ini mencakup seluruh mata uang, yang itu merupakan sasaran terjadinya riba.

Jika ditelaah menggunakan pendapat ketiga, mata uang rupiah dapat dikategorikan sebagai barang ribawiat yang diqiyaskan dengan emas dan perak, karena mata uang rupiah di Indonesia digunakan sebagai alat pembayaran dan sebagai nilai harga barang dan jasa. Maka dari itu ketentuan

${ }^{48}$ Uang kartal adalah uang yang diterbitkan oleh bank sentral berupa kertas atau bentuk logam yang digunakan dalam kehidupan sehari-hari sebagai alat untuk melakukan transaksi. 


\section{Kurnia Cahya, Nashirudin | Jual Beli Mata Kuang Kuno....}

pertukaran mata uang rupiah harus dilakukan secara tunai dengan nominal yang sama.

Proses transaksi jual beli uang kuno sama-sama saling mempertukarkan uang. Namun perbedaan transaksi ini dengan sharf adalah uang yang dijualbelikan atau dipertukarkan itu uang yang sudah tidak berlaku lagi sebagai alat pembayaran yang sah dengan uang yang masih berlaku sebagai alat pembayaran yang sah. Sedangkan sharf adalah pertukaran uang dengan uang yang sama-sama masih berlaku sebagai alat pembayaran yang sah.

Jadi dapat diketahui bahwa mata uang rupiah kuno berbeda dengan mata uang rupiah, karena mata uang rupiah kuno merupakan mata uang yang sudah tidak berlaku lagi di pasaran dan tidak dapat digunakan sebagai alat pembayaran.

Berdasarkan keterangan di atas, mata uang kuno boleh diperjualbelikan meskipun dengan nilai yang lebih besar. Misalnya uang kuno Rp. 500 dijual dengan harga Rp. 15.000,00.

Selain itu mata uang rupiah kuno juga dipandang sebagai barang qimmiyat (barang yang dinilai karena tidak memiliki varian lain serupa), sehingga diperbolehkan melakukan pertukaran dengan nominal yang berbeda. ${ }^{49} \mathrm{Hal}$ itu karena barang-barang qimiyat bukanlah barang yang dapat diukur atau dengan kata lain barang yang satuannya tidak sama ukuran kadarnya. Dalam uang kuno masing-masing memiliki keunikan, seri, dan kualitas yang berbeda-beda antara satu dengan yang lainnya sehingga walaupun sama nominalnya tetapi tidak dapat disamakan.

\footnotetext{
${ }^{49}$ Wahbah Az-Zuhaili, Fqh Islam Wa Adilatuhu..., hlm. 314.
} 


\section{Kurnia Cahya, Nashirudin | Jual Beli Mata Kuang Kuno...}

\section{Kesimpulan}

Pelaksanaan jual beli mata uang rupiah kuno yang terjadi di pasar Triwindu Surakarta dilaksanakan seperti jual beli pada umumnya, di mana si penjual menjual barang dagangannya (mata uang rupiah kuno), dan pembeli membelinya dengan menukarkan barang tersebut dengan sejumlah uang yang telah disepakati bersama, berdasarkan suka sama suka di antara kedua belah pihak. Jual beli tersebut merupakan suatu tindakan yang mengambil manfaat dari mata uang rupiah kuno. Pada umumnya masyarakat yang membeli mata uang rupiah kuno dipergunakan sebagai barang koleksi, mahar pernikahan, alat kesehatan (kerokan), tugas sekolah, dan ada juga yang sengaja dibeli sebagai syarat dalam sebuah ritual.

Hukum jual beli mata uang rupiah kuno yang terjadi di pasar Triwindu Surakarta dinyatakan sah karena pelaksanaannya sudah memenuhi rukun dan syarat jual beli. Selain itu jual beli tersebut juga dipergunakan untuk hal-hal yang tidak bertentangan dengan syariat Islam dan terbebas dari unsur riba.

\section{Daftar Pustaka}

Ahmad, Mustaq. Etika Bisnis dalam Islam. Jakarta: Pustaka Al-Kautsar, 2001.

Al-Mushlih, Abdullah dan Shalah Ash-Shawi. Fikih Ekonomi Keuangan Islam. Jakarta: Darul Haq, 2004.

As-Sa'di, Abdurrahman, dkk,. Fiqih Jual-Beli: Panduan Praktis Bisnis Syariah, terj Abdullah. Jakarta: Senayan Publishing, 2008.

Azwar, Saifudin. Metode Penelitian. Yogyakarta: Pustaka Pelajar, 1998.

Az-Zuhaili, Wahbah. Fiqh Islam Wa Adilatuhu, jilid 5. Jakarta: Gema Ins Basyir, Ahmad Azhar. Asas-Asas Hukum Muamalat (Hukum Perdata Islam). Yogyakarta: UII Press, 2000.

Departeman Agama RI. Al-Qur'an dan Tafsirnya, jilid 2. Jakarta: Lentera Abadi, 2010. 
Djuwaini, Damyauddin. Pengantar Fiqh Muamalah. Yogyakarta: Pustaka Pelajar, 2008.

Fatoni, Siti Nur. Pengantar Ilmu Ekonomi: Dilengkapi Dasar-Dasar Ekonomi Islam. Bandung: Pustaka Setia, 2014.

Hasan, Ahmad. Mata Uang Islami: Telaah Komprehensif Sistem Keuangan Islami terj. Saifurrahman Barito. Zulfikar Ali. Jakarta: PT Raja Grafindo Persada, 2005.

Hidayat, Enang. Fiqih Jual Beli. Bandung: PT Remaja Rosdakarya, 2015.

Karim, Adiwarman A. dan Oni Sahoni. Riba, Gharar dan Kaidah-Kaidah Ekonomi Syariah: Analisis Fikih Ekonomi. Jakarta: Rajawali Pers, 2015.

Khosyi'ah, Siah. Fiqh Muamalah Perbandingan. Bandung: Pustaka Setia, 2014.

Lubis, Suhrawardi K. Hukum Ekonomi Islam. Jakarta: Sinar Grafika, 2004.

Mahalli, Ahmad Mudjab dan Ahmad Rodli Hasbullah. Hadis-Hadis Muttafaq 'Alaih: Bagian Munakahat dan Mu'amalat. Jakarta: kencana, 2004.

Mardani. Fiqh Ekonomi Syariah: Fiqh Muamalah. Jakarta: Kencana, 2012.

Masjupri. Fiqh Muamalah 1. Surakarta: FSEI Publishing, 2013.

Muhammad bin 'Abdurrahman Ad-Dimasyqi. Fiqih Empat Mazhab, terj Abdullah Zaki Alkaf. Bandung: Hasyimi, 2014.

Pusat Pengkajian Hukum Islam dan Masyarakat Madani (PPHIMM). Kompilasi Hukum Ekonomi Syariah,. Jakarta: Kencana, 2009.

Redaksi Konsultasi. "Bolehkah Jual Beli Benda-Benda Antik?", (http://konsultasisyariah.com, 6 Mei 2017).

Syarifuddin, Amir. Garis-Garis Besar Fiqh. Jakarta: Kencana, 2010.

Tarmizi, Erwandi. Harta Haram Muamalat Kontemporer. Bogor: PT Berkat Mulia Insani, 2017. 